\title{
Water retention curve to analyze soil structure changes due to liming
}

\author{
TALITA R. FERREIRA ${ }^{1}$, LUIZ F. PIRES ${ }^{1}$, ANDRÉ C. AULER ${ }^{1}$, ANDRÉ \\ M. BRINATTI ${ }^{1}$ and JOSHUA O. OGUNWOLE ${ }^{2}$ \\ ${ }^{1}$ Laboratório de Física Aplicada a Solos e Ciências Ambientais, Universidade Estadual de Ponta \\ Grossa/UEPG, Av. Gen. Carlos Cavalcanti, 4748, 84030-900 Ponta Grossa, PR, Brasil \\ ${ }^{2}$ Faculty of Agriculture, Department of Soil Science, Federal University Oye- \\ Ekiti, Oye-Are Road, 371104, Oye-Ekiti, Ekiti State, Nigeria \\ Manuscript received on May 27, 2018; accepted for publication on October 11, 2018
}

\begin{abstract}
How to cite: FERREIRA TR, PIRES LF, AULER AC, BRINATTI AM AND OGUNWOLE JO. 2019. Water retention curve to analyze soil structure changes due to liming. An Acad Bras Cienc 91: e20180528. DOI 10.1590/00013765201920180528 .
\end{abstract}

\begin{abstract}
Liming can influence crop growth by altering pore geometry, pore size distribution and water retention characteristics in acid soils. The aim of this work is to determine liming effects on the soil structure based on analysis of water retention data using a cubic spline adjustment function. For that, the authors investigated the effect of three lime rates $(0,15$ and $20 \mathrm{t}$ ha-1) on soil water retention characteristics and pore size distribution of a silty-clay "Cambissolo Háplico Alumínico” (Dystrudept) located in the SE region of the Paraná State, Brazil. Soil cores were collected after 31 months of the experiment at 0-10 cm and 10-20 cm soil layers. Eleven matric potentials (from 0 to $-7000 \mathrm{~cm} \mathrm{H} 2 \mathrm{O}$ ) were employed to calculate soil water retention and pore size distribution curves. The pore size distribution curves revealed trimodal soil porosity with three distinct peaks. Equivalent pore diameters ranging from $9.18 \mu \mathrm{m}$ to $13.18 \mu \mathrm{m}$ separated structural and matrix domains. Small differences exist in the pore size distribution curves due to liming and between layers for all peaks. With no-till plus surface liming, the volume of large pores diminished at the two layers and the volume of small pores increased at the surface layer.
\end{abstract}

Key words: water retention, pore size distribution, soil porosity, acid soils.

\section{INTRODUCTION}

The soil water retention curve (SWRC) and the pore size distribution curve (PSDC) have been widely used to characterize the soil structure (Assouline et al. 1997, Hajnos et al. 2006, Pires et al. 2008, 2017a, Cássaro et al. 2011, Dos Reis

Correspondence to: Talita Rosas Ferreira

Luiz Fernando Pires

E-mail: tali.rf@gmail.com

luizfpires@gmail.com

ORCid: https://orcid.org/0000-0002-7592-1619

https://orcid.org/0000-0001-5073-5900 et al. 2018). The SWRC of structured soils usually presents more than one inflection point, which provide different peaks in the PSDC (Kutílek et al. 2006). The soil porosity is then classified as mono, bi or multimodal, considering the number of peaks in the PSDC (Lu et al. 2014). For instance, bimodal featured soils have their pores possibly occurring in two domains: matrix or textural (intraaggregate pores) and structural (inter-aggregate pores) (Kutílek 2004, Vanderlinden et al. 2017, Zhou et al. 2017). 
In order to determine the SWRC, the van Genuchten model (van Genuchten 1980) is often employed to parameterize data of soil water content $(\theta)$ as function of the matric potential (h) (Auler et al. 2014, 2017b, Pires et al. 2017b, Naveed et al. 2014). Nonetheless, there are other acceptable models currently used to achieve this aim (Fredlund and Xing 1994, Leong and Rahardjo 1997, Karup et al. 2017). The adjustment function referred as cubic spline fits well to almost all $(\theta, \mathrm{h})$ data sets and it provides greater details when interpolating the SWRC (Kastanek and Nielsen 2001). This function makes it possible to identify multimodal structured soils through the PSDC (Lipiec et al. 2006, Ogunwole et al. 2015, Pires et al. 2017c).

Soil acidity is considered a limiting factor to the yield in extensive areas of the world, especially in tropical and subtropical regions. In this way, liming is a known practice to increase the soil $\mathrm{pH}$ and to ameliorate the availability of nutrients such as calcium $(\mathrm{Ca})$ and phosphorum $(\mathrm{P})$ to plants (Edmeades and Ridley 2003). This practice may be applied together with soil tillage operations when a more effective correction of soil acidity is desired, especially over the soil depth (Weirich Neto et al. 2000). Nonetheless, the surface liming (without incorporation methods) is usually chosen when no-till system (NTS) is used (Godsey et al. 2007, Barbieri et al. 2015, Joris et al. 2016, Dos Santos et al. 2018). Caires et al. (2006) showed that surface liming on NTS stood out in terms of soil structure conservation and economic return.

As reported by Schack-Kirchner and Hildebrand (1998), liming stimulates the biological activity and enhances the aeration status of the soil. Haynes and Naidu (1998) highlighted that, in the long-term, liming can raise the soil organic matter content. In turn, Bortoluzzi et al. (2010) verified that the electrochemical changes caused by liming increased the soil aggregate stability. Also, liming has reportedly changed soil physical properties by increasing the volume of total and large voids (equivalent to an area $>1000 \mu \mathrm{m}^{2}$ ) (Grieve et al. $2005)$ and affecting soil water retention and soil porous system (Auler et al. 2017a, b), especially on NTS.

Soil aggregates are preserved when the soil is under NTS, with adequate crop rotation, because it requires minimum soil revolving and consequently avoids soil pore ruptures, providing a more stable porosity (Sauer et al. 1990, Tavares-Filho et al. 2014). Thus, considering that the combination of NTS with liming, in crop rotation systems, is expected to improve the soil porous system, the goals of this study were to investigate possible effects of surface liming on the soil structure as analyzed by water retention data (SWRC and PSDC) using a cubic spline adjustment function.

\section{MATERIAL AND METHODS}

\section{SOIL SAMPLING}

The soil samples were collected in a site located in the SE region of Paraná State $\left(25^{\circ} 28^{\prime} \mathrm{S}, 50^{\circ} 54^{\prime} \mathrm{W}\right.$ and $821 \mathrm{~m}$ a.s.1), Brazil. The soil under study is classified as a Dystrudept silt-clay (Soil Survey Staff 2013) or "Cambissolo Háplico Alumínico" based on the Brazilian System of Soil Classification (Santos et al. 2013). According to the Köppen classification, the region has a humid subtropical climate $(\mathrm{Cfb})$, with average temperature in the coldest month below $18{ }^{\circ} \mathrm{C}$ and the occurrence of frequent frost (mesothermal), mild summers, and average temperature in the hottest month below $22^{\circ} \mathrm{C}$ without a defined dry season. The average annual rainfall is approximately 1,600 $\mathrm{mm}$, and while August is the driest month, January is the month with the highest rainfall (Iapar 2009). The rainfall and temperature data registered from the beginning of the experiment and the region background average are presented in Dos Santos (2015).

Prior to the establishment of the study, the soil had been managed in continuous grazing systems at low stocking rate. In brief, the soil presented 
satisfactory physical quality but severe degradation in terms of acidity and nutrient content, as demonstrated in Dos Santos (2015) and Auler et al. (2017a, b). Twenty days after plants desiccation, in May 2012, 30 $0^{\text {th }}$ lime doses of 0 (L0), 15 (L15) and 20 (L20) tha ${ }^{-1}$ were separately broadcast on the soil surface, in a single dosage, for the conversion of the area from a degraded pastureland to NTS. The experiment was carried out in three bands with 150 $\mathrm{m}^{2}$. The lime rates were calculated to raise the base saturation in the topsoil $(0-20 \mathrm{~cm})$ to $70 \%$ and $90 \%$. The lime used presented 285 and $200 \mathrm{~g} / \mathrm{kg}$ of $\mathrm{CaO}$ and $\mathrm{MgO}$ and 100.6, 74.7 and 75.1\% neutralizing power, reactivity and total neutralizing relative power, respectively.

According to Table I, the crop sequence in the experiment was black oat (Avena strigosa S.) + hairy vetch (Vicia villosa R.), corn (Zea mays L.), black oat, corn, black oat and common bean (Phaseolus vulgaris L.) (Auler et al. 2017a, b). A sowingfertilizing machine equipped with plane discs was used to open furrows and a double disc to deposit fertilizer and seed for the crops sowing (Table I). All crops were conducted without irrigation.

Thirty one months after the liming procedure (between December, 2014 and January, 2015), during the common bean (P. vulgaris L.) reproductive stage period (flowering), aiming to appropriately cover spatial variability, four disturbed soil samples (considered as replications) were collected from each band, at $0-10 \mathrm{~cm}$ and $10-20 \mathrm{~cm}$ soil layers. The 24 undisturbed samples were collected in steel cylinders $(5 \mathrm{~cm}$ high and $4.8 \mathrm{~cm}$ inner diameter), with the help of an Uhland sampler, while the disturbed soil samples were collected using a shovel.

\section{SOIL ANALYSES}

Effects of liming on chemical attributes of the soil under study were published elsewhere (Ferreira et al. 2018a) and are presented in Table II for a better understanding of the effects addressed here.

The excess soil outside the cylinders containing the undisturbed samples was trimmed off and top and bottom surfaces were made flat to ensure that the soil volume was equal to the internal volume of the cylinders. Subsequently, the samples were saturated by capillarity, slowly raising the level of water until right below the superior surface of the samples (Dane and Hopmans 2002).

In order to determine the SWRC, the saturated samples were submitted to the matric potentials

TABLE I

Crop rotation adopted after the experiment was installed.

\begin{tabular}{|c|c|c|c|c|c|}
\hline Crop & Season & Sowing date & $\begin{array}{c}\text { Seed rate } \\
\left(\text { seeds per } \mathbf{m}^{2}\right)\end{array}$ & $\begin{array}{c}\text { Interrow } \\
\text { spacing (m) }\end{array}$ & $\begin{array}{c}\text { Soil } \\
\text { tillage }\end{array}$ \\
\hline $\begin{array}{c}\text { Black oat (Avena strigosa } \mathrm{S} .)+ \\
\text { hairy vetch (Vicia villosa } \mathrm{R} \text {.) }\end{array}$ & Autumn -winter & $\begin{array}{c}\text { May, } 31^{\text {st }} \\
2012\end{array}$ & $200+200$ & $\begin{array}{l}\text { Surface } \\
\text { seeding }\end{array}$ & No \\
\hline Corn (Zea mays L.) & Spring - summer & October, $16^{\text {th }} 2012$ & 8 & 0.90 & $*$ \\
\hline Black oat (Avena strigosa $\mathrm{S}$.) & Autumn -winter & $\begin{array}{c}\text { May, } 18^{\text {th }} \\
2013\end{array}$ & 400 & $\begin{array}{l}\text { Surface } \\
\text { seeding }\end{array}$ & No \\
\hline Corn (Zea mays L.) & Spring - summer & $\begin{array}{l}\text { October, } 22^{\text {nd }} \\
2013\end{array}$ & 8 & 0.90 & $*$ \\
\hline Black oat (Avena strigosa $\mathrm{S}$.) & Autumn -winter & $\begin{array}{c}\text { June, } 02^{\text {nd }} \\
2014\end{array}$ & 400 & $\begin{array}{l}\text { Surface } \\
\text { seeding }\end{array}$ & No \\
\hline $\begin{array}{c}\text { Common bean } \\
\text { (Phaseolus vulgaris L.) }\end{array}$ & Spring - summer & $\begin{array}{l}\text { November, } 10^{\text {th }} \\
2014\end{array}$ & 24 & 0.45 & $*$ \\
\hline
\end{tabular}

*A sowing-fertilizing machine equipped with plane discs was used to open furrows and a double disc to deposit fertilizer and seed, according to NTS. 
TABLE II

Chemical attributes for $0-10 \mathrm{~cm}$ and $10-20 \mathrm{~cm}$ soil layers $(\mathrm{n}=4)$.

\begin{tabular}{|c|c|c|c|c|c|c|}
\hline \multirow{2}{*}{ Lime rate } & \multirow{2}{*}{ pH } & $\mathrm{H}+\mathrm{Al}$ & $\mathrm{Al}^{3+}$ & $\mathrm{Ca}^{2+}$ & $\mathrm{Mg}^{2+}$ & OC \\
\hline & & \multicolumn{4}{|c|}{$\left(\mathrm{cmol}_{\mathrm{c}} \mathrm{dm}^{-3}\right)$} & $\left(\mathrm{g} \mathrm{kg}^{-1}\right)$ \\
\hline \multicolumn{7}{|c|}{$0-10 \mathrm{~cm}$ soil layer } \\
\hline L0 & $3.93(0.11)$ & $15.35(1.41)$ & $4.15(1.09)$ & $1.53(0.85)$ & $2.55(1.44)$ & $36.50(2.65)$ \\
\hline L15 & $5.59(0.72)$ & $4.31(2.06)$ & $0.10(0.14)$ & $8.95(2.63)$ & $4.63(1.32)$ & $42.00(6.16)$ \\
\hline L20 & $5.49(0.48)$ & $4.96(2.11)$ & $0.08(0.05)$ & $7.97(1.75)$ & $5.58(0.88)$ & $35.00(1.83)$ \\
\hline \multicolumn{7}{|c|}{$10-20 \mathrm{~cm}$ soil layer } \\
\hline L0 & $3.89(0.09)$ & $16.84(1.29)$ & $5.85(1.29)$ & $1.05(0.61)$ & $1.02(0.54)$ & $25.25(2.06)$ \\
\hline L15 & $3.98(0.09)$ & $13.78(3.80)$ & $5.73(0.67)$ & $1.16(0.43)$ & $1.33(0.17)$ & $21.00(1.63)$ \\
\hline L20 & $3.99(0.10)$ & $15.62(2.60)$ & $5.90(1.25)$ & $1.30(0.49)$ & $1.76(0.46)$ & $20.50(2.08)$ \\
\hline
\end{tabular}

$\mathrm{pH}=$ in $\mathrm{CaCl}_{2} . \mathrm{H}+\mathrm{Al}=$ potential acidity. $\mathrm{Al}^{3+}, \mathrm{Ca}^{2+}$ and $\mathrm{Mg}^{2+}=$ exchangeable aluminum, calcium and magnesium. OC $=$ organic carbon content (Walkley-Black method). $\mathrm{n}$ represents the number of repetitions and values between parentheses represent the standard deviation.

(h) of $-10,-30,-60$ and $-80 \mathrm{~cm} \mathrm{H}_{2} \mathrm{O}$, in a tension table (M1-0801 model, Eijkelkamp ${ }^{\circledR}$ ), and -100, $-300,-500,-700,-1000,-4000,-7000 \mathrm{~cm} \mathrm{H}_{2} \mathrm{O}$ in a pressure chamber (1500 model, Soil Moisture Equip. Corp. $\left.{ }^{\circledR}\right)$. After the last applied matric potential, the samples were stove $\operatorname{dried}\left(105^{\circ} \mathrm{C} / 48\right.$ h) and their mass was measured using a precision balance. The gravimetric soil water content data were converted to volumetric $(\theta)$ values using the relation between the gravimetric water content and the soil bulk (determined for each sample) and water densities (Klute 1986, Hillel 1998).

Data of $\theta(h)$ was transformed into its parametric form $\mathrm{S}(\mathrm{h})$ (relative saturation) and a cubic spline function was used to fit the experimental data of $\mathrm{S}(\mathrm{h})$ versus $\operatorname{lnh}$ resulting in a smooth curve which represents the SWRC (Kastanek and Nielsen 2001, Kutílek et al. 2006). Water matric potentials were converted to the equivalent pore diameter (d) using the relation $\mathrm{d}=2,980 / \mathrm{h}$, with $\mathrm{d}$ and $\mathrm{h}$ given in $\mu \mathrm{m}$ and $\mathrm{cm}$, respectively (Kutílek and Nielsen 1994). After this transformation, dS/dlnh versus $d$ represented the PSDC.

For SWRC and PSDC, the absolute differences between [L0, L15] and [L0, L20], $\mathrm{S}_{\mathrm{L} 0}-\mathrm{S}_{\mathrm{L} 15 / 20}$ and $\mathrm{dS} / \mathrm{d}(\operatorname{lnh})_{\mathrm{L} 0}-\mathrm{dS} / \mathrm{d}(\operatorname{lnh})_{\mathrm{L} 15 / 20}$, for each layer, was evaluated in order to identify structure changes caused by liming. The absolute difference between the PSDC obtained for $0-10 \mathrm{~cm}$ and $10-20 \mathrm{~cm}$ soil layers, considering each treatment, $\mathrm{dS} / \mathrm{d}(\operatorname{lnh})_{\mathrm{L} 0 / 15 / 20}$

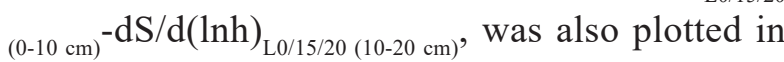
order to highlight the variations in depth.

The SWRCs were also adjusted by the van Genuchten mathematical model, with Mualem's restriction $(\mathrm{m}=1-1 / \mathrm{n})$ (van Genuchten 1980, Mualem 1986):

$\theta=\theta_{\text {res }}+\frac{\left(\theta_{\text {sat }}-\theta_{\text {res }}\right)}{\left[1+(\alpha h)^{n}\right]^{m}}$,

where $\theta_{\text {sat }}$ and $\theta_{\text {res }}$ are the saturation and residual volumetric water contents, respectively; $\alpha, n$ and $m$ are empirical adjustment parameters of the model, which depend on the shape of the $\theta(h)$ curve. The parameters of adjustment were obtained by the software SWRC FIT (Seki 2007).

Linear correlation analyses were performed between volume data in terms of relative saturation (S) obtained through the cubic spline and van Genuchten adjustments. In this case, the classes of pore size $\left(f_{0.5-50 \mu \mathrm{m}}, f_{50-500 \mu \mathrm{m}}, f_{>500 \mu \mathrm{m})}\right.$ were defined in terms of d, as established by Greenland (1977), depending on the hydraulic role played by the different sized pores (Table III). Considering the 
TABLE III

Classification of soil pores according to their hydraulic function (Greenland 1977).

\begin{tabular}{|c|c|c|}
\hline Classification & $\begin{array}{l}\text { Equivalent pore } \\
\text { diameter }(\mu \mathrm{m})\end{array}$ & Hydraulic function \\
\hline Storage pores & $0.5-50$ & $\begin{array}{c}\text { Hold water } \\
\text { sufficiently strong } \\
\text { not to drain readily } \\
\text { but still release water } \\
\text { to plants. }\end{array}$ \\
\hline $\begin{array}{c}\text { Transmission } \\
\text { pores/ Fissures }\end{array}$ & $50-500 />500$ & $\begin{array}{l}\text { Air movement and } \\
\text { drainage of excess } \\
\text { water. }\end{array}$ \\
\hline
\end{tabular}

cubic spline adjustment, the sum of the volumes obtained for peaks 1 and 2 (Fig. 1) corresponds to the volume of pores enclosed by the $f_{0.5-50 \mu \mathrm{m}}$ class and the volume obtained for the peak 3 corresponds to the volume of pores enclosed by the $f_{50-500 \mu \mathrm{m}}$ class (Table III). Considering the van Genuchten adjustment, the volumes of the $f_{0.5-50 \mu \mathrm{m}}$ and $f_{50-500 \mu \mathrm{m}}$ classes are equal to the difference between the $\mathrm{S}(\mathrm{d})$ values for $0.5 \mu \mathrm{m} \leq \mathrm{d} \leq 50 \mu \mathrm{m}$ and $50 \mu \mathrm{m} \leq \mathrm{d} \leq 500$ $\mu \mathrm{m}$, respectively.

\section{RESULTS}

From the SWRCs (Fig. 2a-b), it is possible to observe that L15 and L20 present similar behavior in comparison to L0, at both soil layers. This is highlighted in Fig. 2c-d, which show the absolute difference between $\mathrm{S}(\mathrm{h})$ values for L15 and $\mathrm{L} 20$ in relation to $\mathrm{L} 0$. At $0-10 \mathrm{~cm}$ soil layer, the arrangement of pores is such that the water is slightly less strongly retained in L15 and L20, in comparison with $\mathrm{L} 0$, considering high matric potentials $(0<\operatorname{lnh}<4)$. At lower matric potentials $(\operatorname{lnh}>4)$, the water retention becomes stronger for L15 and L20 in relation to L0 (Fig. 2a, c). On the other hand, at 10-20 cm soil layer, L20 presents a slightly stronger water holding for all matric potentials (Fig. 2b, d).

All treatments presented PSDCs containing three distinct peaks (Fig. 2e-f), which led to the consideration of the soil porosity as being trimodal

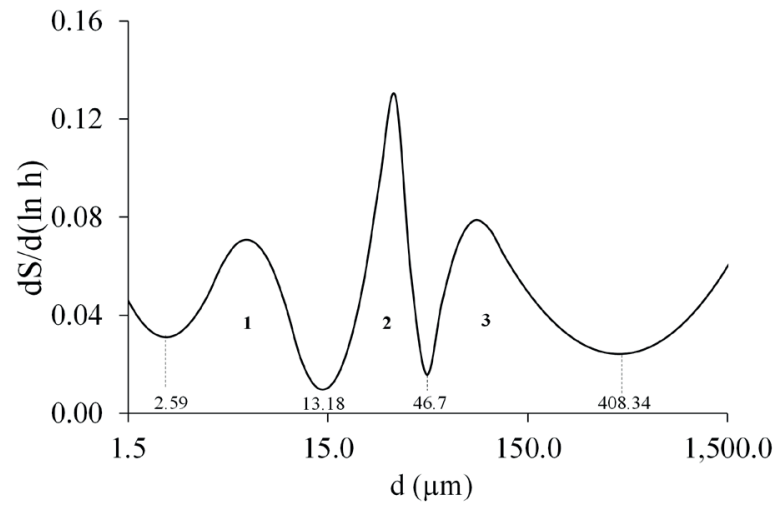

Figure 1 - Typical pore size distribution curve (PSDC) obtained through the cubic spline adjustment. The numbered peaks correspond to the matrix (1) and structural (2 and 3) porosity domains.

(Kutílek 2004). Peaks 1, 2 and 3 typically represent the matrix and structural porosity domains as exemplified in Fig. 1. The structural and matrix domains are separated by d varying from $9.18 \mu \mathrm{m}$ to $13.18 \mu \mathrm{m}$ (Fig. 2e-f).

The peaks position in the structural domain (32.54 $\mu \mathrm{m}$ and $80.32 \mu \mathrm{m})$ did not vary neither due to lime treatments on NTS, within each layer, nor between soil layers for each lime treatment (Fig. 2e-f). In the matrix domain, at both soil layers, L0 and L15 presented peaks associated to smaller d sizes $(3.72 \mu \mathrm{m})$ in comparison with L20 (4.46 $\mu \mathrm{m}-0-10 \mathrm{~cm} ; 5.34 \mu \mathrm{m}-10-20 \mathrm{~cm}$ ) (Fig. 2e-f). This means that the higher dose of surface lime can influence on the increase of the main $d$ of the intra-aggregate pores responsible for the high water retention. Besides, with the lime doses, the separation between the peaks from matrix and structural domains became better defined.

The absolute difference between the $\mathrm{S}(\mathrm{d})$ value for two successor lower PSDC points give the volume of pores enclosed by each of the peaks (1,2 and 3) illustrated in Fig. 1. Thus, the volumes corresponding to the peaks 1, 2 and 3 in Fig. 2e-f were plotted as function of the treatments (L0, L15 and L20) in Fig. 3. 

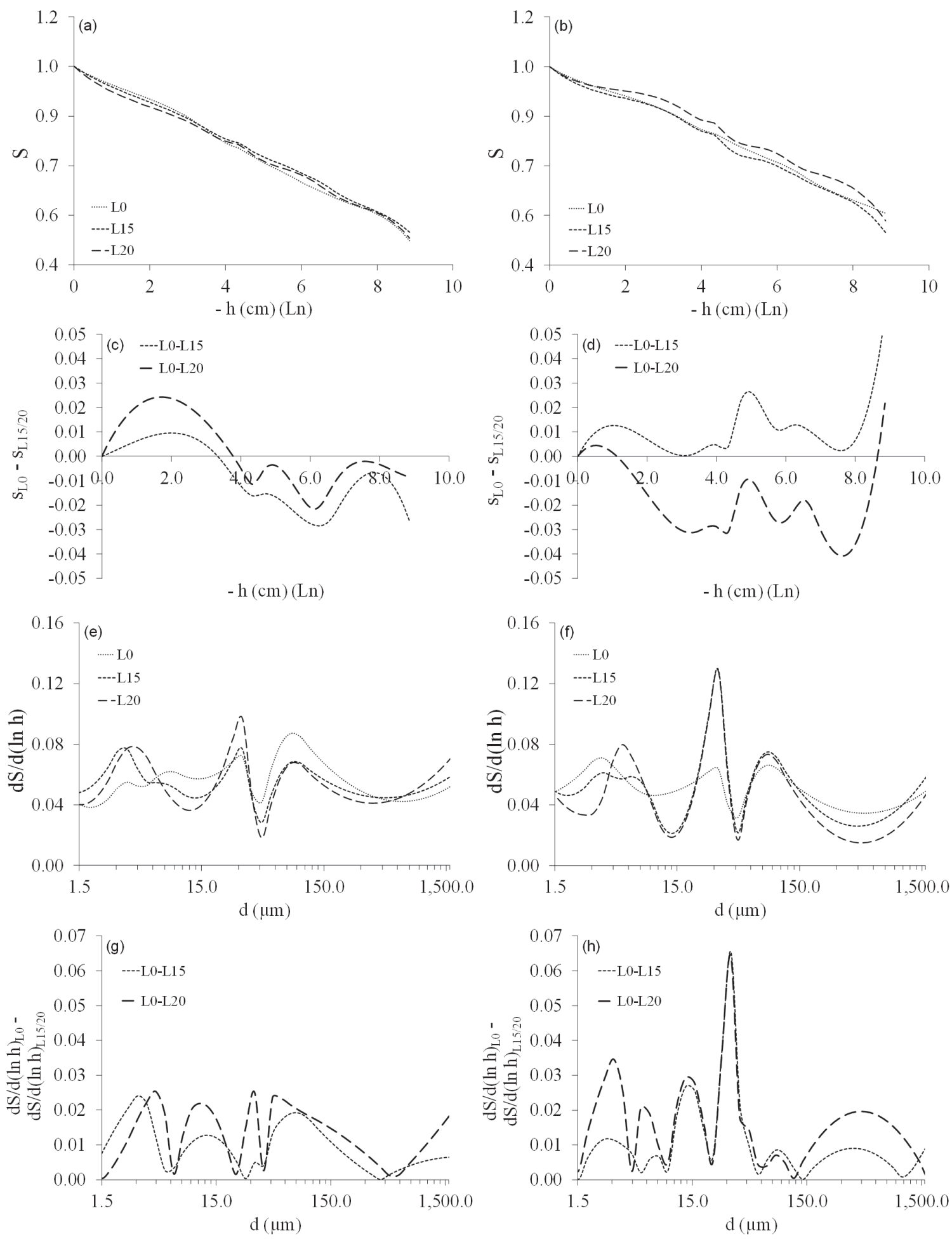

Figure 2 - Soil water retention curves (SWRC), absolute difference between SWRC obtained for L0 and the remaining treatments (L15 and L20), pore size distribution curves (PSDC) and absolute difference between PSDC obtained for L0 and the remaining treatments (L15 and L20) for 0-10 $\mathrm{cm}(\mathbf{a}, \mathbf{c}, \mathbf{e}, \mathbf{g})$ and 10-20 $\mathrm{cm}(\mathbf{b}, \mathbf{d}, \mathbf{f}, \mathbf{h})$ soil layers, respectively. 

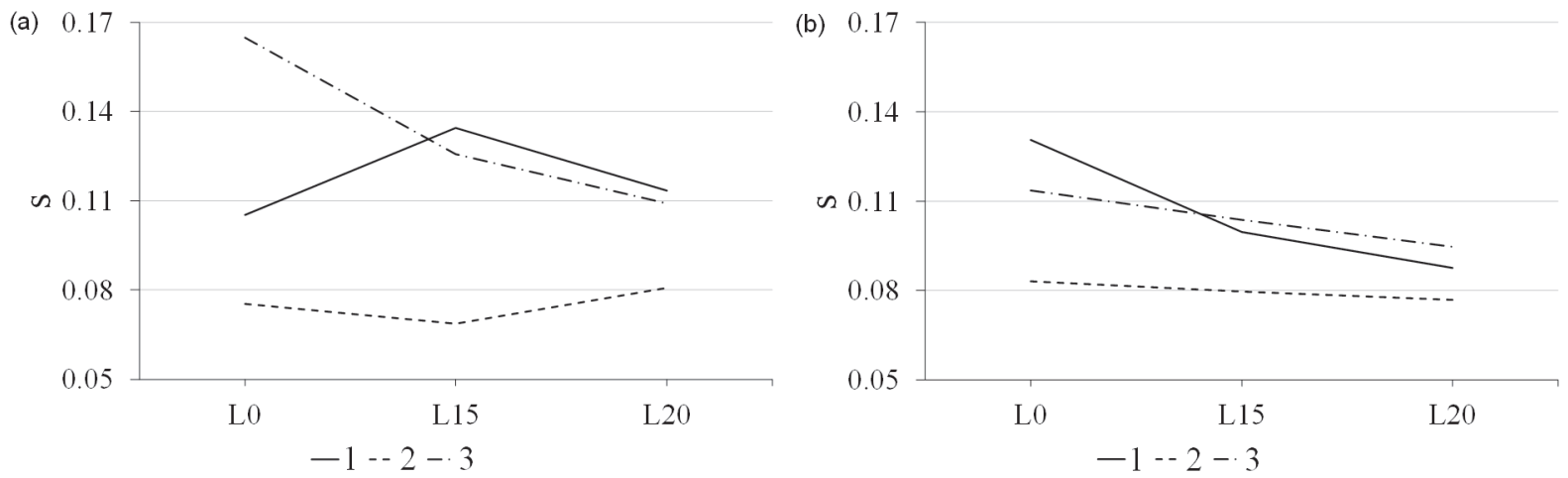

Figure 3 - Pore volumes enclosed by the peaks located in the matrix (1) and structural (2 and 3) porosity domain (see Fig. 1) as a function of the treatments for the (a) $0-10 \mathrm{~cm}$ and (b) $10-20 \mathrm{~cm}$ soil layers.

As seen in Fig. 3a, at $0-10 \mathrm{~cm}$, the pore volume enclosed by peak 3 is larger than the pore volume associated to the peak 2 , for all treatments. However, from L0 on, the pore volume decreases for peak 3 and, at last, the pore volumes for peaks 2 and 3 turn close. Still in Fig.3a, the pore volume related to the peak 1 (matrix domain) undergoes an increase for L15 and L20 in comparison to L0. In this context, L15 and L20 count on a higher proportion of pore volume in the matrix region than in the structural region associated with peak 3 . According to Table 3 , a higher contribution of the pore volume in the matrix region should promote greater capacity of soil water retention.

The same approaching trend observed at 0-10 $\mathrm{cm}$ between the pore volumes ascribed to the peaks in the structural domain (2 and 3) (Fig. 3a) is seen at $10-20 \mathrm{~cm}$ from L0 to L15 and L20 (Fig. 3b). On the other hand, at $10-20 \mathrm{~cm}$, the pore volume enclosed by the peak in the matrix domain (1) decreases from L0 to L15 and L20, becoming inferior to the pore volume of peak 3 . Nevertheless, the water holding conditions are still favorable to L15 and L20 since, in these cases, the pore volume of peak 3 is somewhat lower than that for L0.

As can be seen in Fig. $2 \mathrm{~g}$, at $0-10 \mathrm{~cm}$, the PSDCs for L15 and L20 show similar absolute difference in relation to L0 in the matrix domain.
Hence, it is reasonable to admit that the different lime doses increased not only the volume (Fig. 3a) but also the frequency of intra-aggregate pores (Fig $2 \mathrm{~g}$ ) in a very close extend. Still at $0-10 \mathrm{~cm}$, considering the structural domain, L20 presents larger absolute difference than L15 in relation to L0, mainly in the region of peak 2 (Fig. 2g), which is in line with the increase in volume associated to this peak (Fig. 3a).

At $10-20 \mathrm{~cm}, \mathrm{~L} 20$ presents considerably larger difference than L15 in relation to L0 in the matrix domain (Fig. 2h). In the structural domain, although the volumes of pores enclosed by peaks 2 and 3 underwent a slightly decrease from L0 to L15 and L20 (Fig. 3b), L15 and L20 caused similar increasing effect on the frequency of pores (Fig. 2h).

The difference on PSDC between layers is small for all peaks of L0 (Fig. 4a-b). On the other hand, for L15 (Fig. 4c-d) and L20 (Fig. 4ef), the differences between layers become more pronounced, mainly considering the first peak of the structural domain.

As can be seen in Table IV, the pore volumes of the $f_{0.5-50 \mu \mathrm{m}}$ and $f_{50-500 \mu \mathrm{m}}$ classes found by the van Genuchten adjustment overestimate those found by the cubic spline adjustment. It happens because, in the cubic spline adjustment, the evaluated pore classes are limited not exactly by $d$ values in the 
TABLE IV

Volume data in terms of relative saturation (S) obtained through the cubic spline and van Genuchten adjustments, for $f_{0.5-50}$ and $f_{50-500}$ classes of pore size, and linear correlation coefficients of Pearson ( $r$ ) considering both adjustments for 0-10 cm and $10-20 \mathrm{~cm}$ soil layers.

\begin{tabular}{|c|c|c|c|c|c|c|}
\hline \multirow[b]{2}{*}{ Lime rate } & \multicolumn{3}{|c|}{$f_{0.5-50}$} & \multicolumn{3}{|c|}{$f_{50-500}$} \\
\hline & $\begin{array}{c}\text { S } \\
\text { Cubic Spline }\end{array}$ & $\begin{array}{c}\text { S van } \\
\text { Genuchten }\end{array}$ & $\mathbf{r}$ & $\begin{array}{c}\text { S } \\
\text { Cubic Spline }\end{array}$ & $\begin{array}{c}\text { S van } \\
\text { Genuchten }\end{array}$ & $\mathbf{r}$ \\
\hline \multicolumn{7}{|c|}{$0-10 \mathrm{~cm}$ soil layer } \\
\hline 0 & 0.181 & 0.269 & -1.000 & 0.165 & 0.148 & 0.998 \\
\hline 15 & 0.203 & 0.253 & & 0.126 & 0.137 & \\
\hline 20 & 0.194 & 0.259 & & 0.109 & 0.131 & \\
\hline \multicolumn{7}{|c|}{$10-20 \mathrm{~cm}$ soil layer } \\
\hline 0 & 0.214 & 0.241 & -1.000 & 0.113 & 0.121 & 0.678 \\
\hline 15 & 0.179 & 0.263 & & 0.104 & 0.128 & \\
\hline 20 & 0.164 & 0.273 & & 0.095 & 0.105 & \\
\hline
\end{tabular}

0.5-50 $\mu \mathrm{m}$ and 50-500 $\mu \mathrm{m}$ intervals, but instead by the boundaries of the peaks $(1+2)$ and (3) (Fig. 1). Consistent correlations between the volumes estimated through van Genuchten and cubic spline adjustments were determined for both pore volume classes and both considered soil layers.

\section{DISCUSSION}

Surface liming might change soil water retention processes and pore size distribution (Auler et al., 2017a, b, Auler 2018). Regarding the changes seen in $\mathrm{d}$ in the matrix domain (Fig. 2e-f), a possible explanation might be related to the fact that a higher proportion of $\mathrm{CaO}$ was found for $\mathrm{L} 20\left(68.71 \mathrm{~g} \mathrm{~kg}^{-1}\right)$ in comparison with L15 (22.69 $\left.\mathrm{g} \mathrm{kg}^{-1}\right)$ and L0 (0 $\mathrm{g} \mathrm{kg}^{-1}$ ) by X-ray fluorescence analysis (Ferreira et al. 2018a). As a consequence, it is likely that L20 also has a higher Calcite contribution resulted from the non-reacted lime added fraction, which end up leading to crust formation (Valdes-Abellan et al. 2017). These mineral clusters not only present inner porosity but also may fit to the soil particles in a way that the matrix porosity is modified.

Since no acidity improvement was seen at 10-20 cm (Table 2), a hypothesis for explaining the higher absolute differences between PSDCs observed at this layer (Fig. 2h) could be an indirect effect of the enhanced root development that is expected as consequence of liming (Castro and Crusciol 2013). In addition, Ferreira et al. (2018b) showed that, although the soil acidity attributes were not affected by liming at $10-20 \mathrm{~cm}$, the pattern of pores was modified by liming at both soil layers (0-10 $\mathrm{cm}$ and 10-20 cm), with the formation of cylindrical horizontally oriented pores, which are probably due to stimulation of earthworm activity.

The largest pore volume in the region of the matrix domain of L15 and L20 in relation to the structural domain (Fig. 3a) might be attributed to alterations in the process of soil aggregation due to liming (Auler et al. 2017a). It has been frequently reported that liming initially acts increasing the dispersion of particles in the soil as a consequence of its increased soil pH (Roth and Pavan 1991). On the other hand, the dispersive effect is suppressed over time by the increase of the ionic strength of the soil solution due to the contribution of $\mathrm{Ca}^{2+}$ and $\mathrm{Mg}^{2+}$ ions, which favors the flocculation of the dispersed particles (Haynes and Naidu 1998, Bronick and Lal 2005, Auler et al. 2017a). Additionally, $\mathrm{Ca}^{2+}$ and $\mathrm{Mg}^{2+}$ ions start replacing $\mathrm{Al}^{3+}$ on the surface of clay particles (soil exchange complex) (Sparks 2003).

The flocculation process as well as the

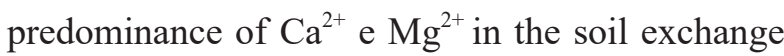



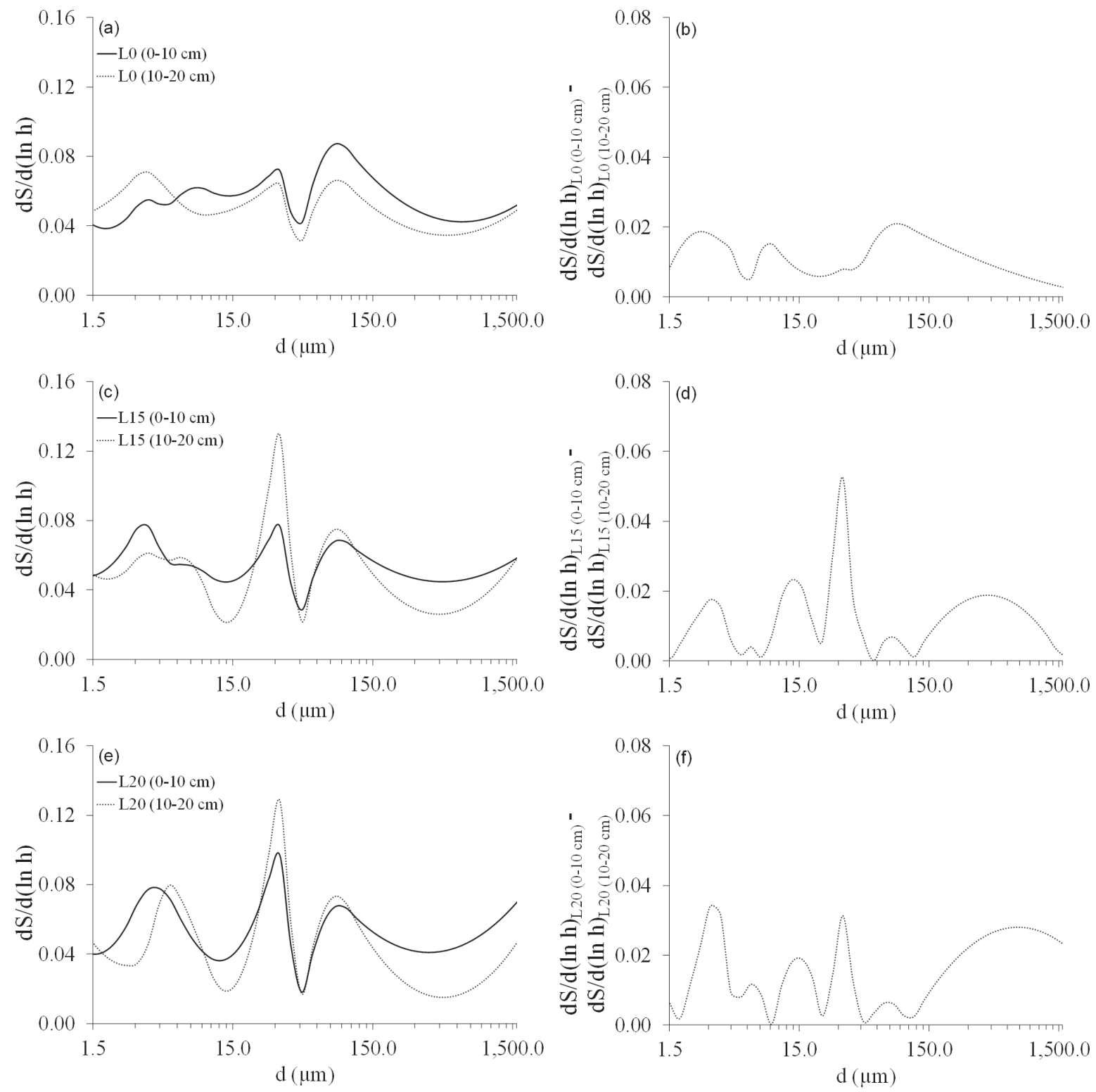

Figure 4 - Pore size distribution curves (PSDC) for 0-10 cm and 10-20 cm soil layers and the absolute difference between these curves for L0 (a, b), L15 (c, d), and L20 (e, f) treatments, respectively.

complex, which are smaller than $\mathrm{Al}^{3+}$ (Sparks 2003), are known for affecting the soil aggregation (Edwards and Bremner 1967, Baldock et al. 1994, Briedis et al. 2012). The flocculated particles tend to be closer to each other (Khorshidi and $\mathrm{Lu} 2016$ ) so that the volume of intra-aggregate pores tends to be increased. Such hypotheses corroborate with the findings of Auler et al. (2017b). These authors verified that the soil microporosity $(\mathrm{d}<50 \mu \mathrm{m})$ and the water retention at $0-10 \mathrm{~cm}$ were increased with a $15 \mathrm{tha}^{-1}$ lime rate in comparison to the non-limed soil.

On the other hand, in the structural domain (Fig. 3), the results might be related to biopore formation in the soil through (i) the slow and gradual decomposition of the fasciculate roots and stolons of the forage which covered the area prior 
to the experiment installation; (ii) crop root growth increases; and (iii) higher density and activity of the soil macrofauna (Auler et al. 2017b).

The present study is innovative concerning the investigation of liming effects on the multimodality of soil porosity. However, previous studies have investigated the multimodality of the soil porosity due to different tillage practices (Lipiec et al 2006, Cássaro et al. 2011, Pires et al. 2017c), different types of soils (Pires et al. 2008), and different fertilization regimes (Zhou et al. 2017). For example, Cássaro et al. (2011) verified a trimodal porosity for a "Latossolo Vermelho" (Santos et al. 2013), or Rhodic Ferralsol (FAO 1998), under NTS and the authors demonstrated that this soil presented comparable PSDCs to all investigated layers $(0-10,10-20$, and $20-30 \mathrm{~cm})$. This is in line with the similarities found on PSDCs between soil layers for L0 (Fig. 4a-b), which has only the NTS effect (no lime application).

Ferreira et al. (2018b) used X-ray microtomography images to analyze effects of liming on the porous system of the same soil considered here. The mentioned authors found no significant difference on soil porosity and number of pores (for a voxel size of $60 \mu \mathrm{m}$ ) between soil layers $(0-10 \mathrm{~cm}$ and $10-20 \mathrm{~cm})$ for L0 but, for L20, the $0-10 \mathrm{~cm}$ layer was found to be more porous with fewer isolated pores in comparison with $10-20 \mathrm{~cm}$. These results corroborate the greater differences of PSDCs determined between layers for L15 and L20 (Fig. 4d, f) in relation to L0 (Fig. 4b).

\section{CONCLUSIONS}

1. The silty-clay "Cambissolo Háplico Alumínico" (Dystrudept) presented a trimodal porosity when analyzed by the cubic spline adjustment considering all treatments (no-till system without liming and no-till system with different lime doses) and both layers $(0-10 \mathrm{~cm}$ and $10-20 \mathrm{~cm})$. Yet, greater changes among treatments were found in the matrix than in the structural domain for both layers;

2. Based on the cubic spline analyses, no-till with surface liming has diminished the volume of larger pores (known as transmission pores) both at $0-10 \mathrm{~cm}$ and at $10-20 \mathrm{~cm}$ soil layers. Besides, it enlarged the volume of smaller pores (storage pores) at the surface layer;

3. Good correlation was found between volume of pores attributed to corresponding classes of pore size determined by the cubic spline and van Genuchten adjustments. However, the considered adjustments did not agree quantitatively with each other: overestimation of pore volumes determined by van Genuchten in relation to cubic spline.

\section{ACKNOWLEDGMENTS}

This study was financed in part ( $\mathrm{PhD}$ grant for TRF and ACA) by the Coordenação de Aperfeiçoamento de Pessoal de Nível Superior - Brasil (CAPES) Finance Code 001. LFP acknowledges Conselho Nacional de Desenvolvimento Científico e Tecnológico (CNPq) for the research grant (303726/2015-6). The authors would also like to thank Dr. Jadir A. Rosa and Dr. José A. Baptista dos Santos from Iapar for the infrastructure and experimental area support.

\section{AUTHOR CONTRIBUTIONS}

TRF and ACA collected the soil samples and performed all experimental procedures. TRF and LFP conducted the data analysis. TRF wrote the paper and all authors contributed toward interpreting the results, revising, and improving the paper.

\section{REFERENCES}

ASSOULINE S, TESSIER D AND TAVARES-FILHO J. 1997. Effect of compaction on soil physical and hydraulic properties: Experimental results and modeling. Soil Sci Soc America J 61: 390-398. 
AULER AC. 2018. Efeitos de corretivos da acidez do solo associados ao gesso agricola sobre os atributos físicos e químicos do solo. Ph.D. Thesis, Ponta Grossa: Universidade Estadual de Ponta Grossa, 134 p.

AULER AC, MIARA S, PIRES LF, DA FONSECA AF AND BARTH G. 2014. Soil physico-hydrical properties resulting from the management in Integrated Production Systems. Rev Ciência Agronômica 45: 976-989.

AULER AC, PIRES LF AND CAIRES EF. 2017a. Surface and incorporated liming effects on clay dispersion, water availability, and aeration capacity of a Dystrupded soil. Bragantia 76: 433-446.

AULER AC, PIRES LF, DOS SANTOS JAB, CAIRES EF, BORGES JAR AND GIAROLA NFB. 2017b. Effects of surface-applied and soil-incorporated lime on some physical attributes of a Dystrudept soil. Soil Use Manag 33: 129-140.

BALDOCK JA, AOYAMA M, OADES JM, SUSANTO O AND GRANT CD. 1994. Structural Amelioration of a South Australian red-brown earth using calcium and organic amendments. Aust J Soil Res 32: 571-594.

BARBIERI PA, ECHEVERRÍA HE, SAINZ ROZAS HR AND MARTÍNEZ JP. 2015. Soybean and wheat response to lime in no-till Argentinean mollisols. Soil Tillage Res 152: 29-38.

BORTOLUZZI EC, POLETO C, BAGINSKI ÁJ AND DA SILVA VR. 2010. Aggregation of subtropical soil under liming: a study using laser diffraction. Rev Bras Ciência do Solo 34: 725-734.

BRIEDIS C, SÁ JCM, CAIRES EF, NAVARRO JF, INAGAKI TM, BOER A, NETO CQ, FERREIRA AO, CANALLI LB AND DOS SANTOS JB. 2012. Soil organic matter pools and carbon-protection mechanisms in aggregate classes influenced by surface liming in a no-till system. Geoderma 170: 80-88.

BRONICK CJ AND LAL R. 2005. Soil structure and management: a review. Geoderma 124: 3-22.

CAIRES EF, BARTH G AND GARBUIO FJ. 2006. Lime application in the establishment of a no-till system for grain crop production in Southern Brazil. Soil Tillage Res 89: 3-12.

CÁSSARO FAM, BORKOWSKI AK, PIRES LF, ROSA JA AND SAAB SC. 2011. Characterization of a Brazilian clayey soil submitted to conventional and no-tillage management practices using pore size distribution analysis. Soil Tillage Res 111: 175-179.

CASTRO GSA AND CRUSCIOL CAC. 2013. Effects of superficial liming and silicate application on soil fertility and crop yield under rotation. Geoderma 195: 234-242.

DANE JH AND HOPMANS JW. 2002. Water retention and storage. In: Dane JH and Topp GC (Eds), Methods of Soil Analysis. Part 4: Physical Methods, Madison: Soil Science Society of America, Madison, WI, p. 671-690.

DOS REIS AM, ARMINDO RA, DURAES MF, LIER QJV. 2018. Evaluating pedotransfer functions of the Splintex model. Eur J Soil Sci 69(4): 685-697.
DOS SANTOS DR, TIECHER T, GONZATTO R, SANTANNA MA, BRUNETTO G, DA SILVA LS. 2018. Long-term effect of surface and incorporated liming in the conversion of natural grassland to no-till system for grain production in a highly acidic sandy-loam Ultisol from South Brazilian Campos. Soil Tillage Res 180: 222-231.

DOS SANTOS JAB. 2015. Qualidade física de um Cambissolo Háplico Alumínico submetido a doses e formas de aplicação de calcário. Ph.D. Thesis, Ponta Grossa: Universidade Estadual de Ponta Grossa, 95 p.

EDMEADES DC AND RIDLEY AM. 2003. Using Lime to Ameliorate Topsoil and Subsoil Acidity. In: Rengel Z (Ed), Handbook of Soil Acidity, New York: Marcel Dekker AG, New York, USA, 40 p.

EDWARDS AP AND BREMNER JM. 1967. Microaggregates in Soil. J Soil Sci 18: 64-73.

FAO. 1998. World Reference Base for Soil Resources. FAO, ISRIC and ISSS, Rome, Italy.

FERREIRA TR, PIRES LF, BRINATTI AM AND AULER AC. 2018a. Surface liming effects on soil radiation attenuation properties. J Soils Sediments 18: 1641-1653.

FERREIRA TR, PIRES LF, WILDENSCHILD D, HECK RJ AND ANTONINO ACD. 2018b. X-ray microtomography analysis of lime application effects on soil porous system. Geoderma 324: 119-130.

FREDLUND DG AND XING A. 1994. Equations for the soilwater characteristic curve. Can Geotech J 31: 521-532.

GODSEY CB, PIERZYNSKI GM, MENGEL DB AND LAMOND RE. 2007. Management of Soil Acidity in NoTill Production Systems through Surface Application of Lime. Agron J 99: 764.

GREENLAND DJ. 1977. Soil damage by intensive arable cultivation: temporary or permanent? Philos Trans R Soc London B 281: 193-208.

GRIEVE IC, DAVIDSON DA AND BRUNEAU PMC. 2005. Effects of liming on void space and aggregation in an upland grassland soil. Geoderma 125: 39-48.

HAJNOS M, LIPIEC J, ŚWIEBODA R, SOKOŁOWSKA Z AND WITKOWSKA-WALCZAKA B. 2006. Complete characterization of pore size distribution of tilled and orchard soil using water retention curve, mercury porosimetry, nitrogen adsorption, and water desorption methods. Geoderma 135: 307-314.

HAYNES RJ AND NAIDU R. 1998. Influence of lime, fertilizer and manure applications on soil organic matter content and soil physical conditions: a review. Nutr $\mathrm{Cycl}$ Agroecosystems 51: 123-137.

HILLEL D. 1998. Environmental Soil Physics: Fundamentals, Applications, and Environmental Considerations. London: Academic Press, $771 \mathrm{p}$.

IAPAR - INSTITUTO AGRONÔMICO DO PARANÁ. 2009. Cartas climáticas do Paraná: classificação climática segundo Köppen. Londrina: IAPAR.

JORIS HAW, CAIRES EF, SCHARR DA, BINI ÂR AND HALISKI A. 2016. Liming in the conversion from 
degraded pastureland to a no-till cropping system in Southern Brazil. Soil Tillage Res 162: 68-77.

KARUP D, MOLDRUP P, TULLER M, ARTHUR E AND DE JONGE LW. 2017. Prediction of the soil water retention curve for structured soil from saturation to oven-dryness. Eur J Soil Sci 68: 57-65.

KASTANEK FJ AND NIELSEN DR. 2001. Description of Soil Water Characteristics Using Cubic Spline Interpolation. Soil Sci Soc Am J 65: 279.

KHORSHIDI M AND LU N. 2016. Intrinsic relation between soil water retention and cation exchange capacity. J Geotech Geoenviron Engineering 143(4): 04016119.

KLUTE A. 1986. Water Retention: Laboratory Methods. In: Klute A (Ed), Methods of Soil Analysis: Part 1 - Physical and Mineralogical Methods, Madison: American Society of Agronomy, Soil Science Society of America Book Series, Madison, USA, p. 635-662.

KUTÍLEK M. 2004. Soil hydraulic properties as related to soil structure. Soil Tillage Res 79: 175-184.

KUTÍLEK M, JENDELE L AND PANAYIOTOPOULOS KP. 2006. The influence of uniaxial compression upon pore size distribution in bi-modal soils. Soil Tillage Res 86: 27-37.

KUTÍLEK M AND NIELSEN DR. 1994. Soil Hydrology. Germany: Catena Verlag, $370 \mathrm{p}$.

LEONG EC AND RAHARDJO H. 1997. Review of SoilWater Characteristic Curve Equations. J Geotech Geoenvironmental Eng 123: 1106-1117.

LIPIEC J, KUŚ J, SŁOWIŃSKA-JURKIEWICZ A AND NOSALEWICZ A. 2006. Soil porosity and water infiltration as influenced by tillage methods. Soil Tillage Res 89: 210-220.

LU SG, MALIK Z, CHEN DP AND WU CF. 2014. Porosity and pore size distribution of Ultisols and correlations to soil iron oxides. Catena 123: 79-87.

MUALEM Y. 1986. Hydraulic conductivity of unsaturated soils: prediction and formulas. In: Klute A (Ed), Methods of Soil Analysis. I. Physical and Mineralogical Methods, Madison: ASA, SSSA, Madison, USA, p. 799-823.

NAVEED M, MOLDRUP P, VOGEL H-JÖ, LAMANDÉ M, WILDENSCHILD D, TULLER M AND DE JONGE LW. 2014. Impact of long-term fertilization practice on soil structure evolution. Geoderma 217: 181-189.

OGUNWOLE JO, PIRES LF AND SHEHU BM. 2015. Changes in the Structure of a Nigerian Soil under Different Land Management Practices. Rev Bras Ciência do Solo 39: 830-840.

PIRES LF, ARAUJO-JUNIOR CF, AULER AC, DIAS NMP, DIAS JUNIOR MS AND DE ALCÂNTARA EN. 2017a. Soil physico-hydrical properties changes induced by weed control methods in coffee plantation. Agric Ecosyst Environ 246: 261-268.

PIRES LF, ARAUJO-JUNIOR CF, DIAS NMP, DIAS JUNIOR MS AND DE ALCÂNTARA EN. 2017b. Weed control methods effect on the hydraulic attributes of a Latosol. Acta Sci Agron 39: 119-128.
PIRES LF, BORGES JAR, ROSA JA, COOPER M, HECK RJ, PASSONI S AND ROQUE WL. 2017c. Soil structure changes induced by tillage systems. Soil Tillage Res 165 : 66-79.

PIRES LF, CÁSSARO FAM, REICHARDT K AND BACCHI OOS. 2008. Soil porous system changes quantified by analyzing soil water retention curve modifications. Soil Tillage Res 100: 72-77.

ROTH CH AND PAVAN MA. 1991. Effects of lime and gypsum on clay dispersion and infiltration in samples of a Brazilian Oxisol. Geoderma 48: 351-361.

SANTOS HG, JACOMINE PKT, ANJOS LHC, OLIVEIRA VA, LUMBRERAS JF, COELHO MR, ALMEIDA JA, CUNHA TJF. AND OLIVEIRA JB. 2013. Sistema brasileiro de classificação de solos. Rio de Janeiro: Embrapa Solos.

SAUER TJ, CLOTHIER BE AND DANIEL TC. 1990. Surface measurements of the hydraulic properties of a tilled and untilled soil. Soil Tillage Res 15: 359-369.

SCHACK-KIRCHNER H AND HILDEBRAND EE. 1998. Changes in soil structure and aeration due to liming and acid irrigation. Plant Soil 199: 167-176.

SEKI K. 2007. SWRC fit - na nonlinear fitting program with a water retention curve for soils having unimodal and bimodal pore structure. Hydrol Earth Syst Sci Discuss 4: 407-437.

SOIL SURVEY STAFF. 2013. Simplified guide to soil taxonomy. USDA-Natural Resources Conservation Service, National Soil Survey Center, Lincoln, USA.

SPARKS DL. 2003. Environmental Soil Chemistry. San Diego: Elsevier, 352 p.

TAVARES-FILHO J, MELO TRD, MACHADO W AND MACIEL BV. 2014. Structural changes and degradation of Red Latosols under different management systems for 20 years. Rev Bras Ci Solo 38:1293-1303.

VALDES-ABELLAN J, JIMÉNEZ-MARTÍNEZ J, CANDELA L, JACQUES D, KOHFAHL C AND TAMOH K. 2017. Reactive transport modelling to infer changes in soil hydraulic properties induced by non-conventional water irrigation. J Hydrol 549: 114-124.

VAN GENUCHTEN MT. 1980. A closed-form equation for predicting the hydraulic conductivity of unsaturated soils. Soil Sci Soc Am J 44: 895-989.

VANDERLINDEN K, PACHEPSKY YA, PEDERERAPARRILLA A, MARTÍNEZ G, ESPEJO-PÉREZ AJ, PEREA F, GIRÁLDEZ JV. 2017. Water Retention and Preferential States of Soil Moisture in a Cultivated Vertisol. Soil Sci Soc Am J 81(1): 1-9.

WEIRICH NETO PH, CAIRES EF, JUSTINO A AND DIAS J. 2000. Correction of soil acidity in function of lime incorporation manners. Ciência Rural 30: 257-261.

ZHOU H, MOONEY SJ AND PENG X. 2017. Bimodal Soil Pore Structure Investigated by a Combined Soil Water Retention Curve and X-Ray Computed Tomography Approach. Soil Sci Soc Am J 81(6): 1270-1278. 